\title{
Hydroxyapofylit-(K) z kamenolomu Těchlovice u Děčína (Česká republika)
}

\author{
Hydroxyapophyllite-(K) from quarry Těchlovice near Děčín (Czech Republic)
}

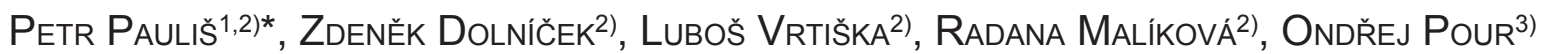 \\ A FERRY FEDIUK ${ }^{4}$ \\ 1)Smíškova 564, 28401 Kutná Hora; *e-mail petr.paulis@post.cz \\ ${ }^{2)}$ Mineralogicko-petrologické oddělení, Národní muzeum, Cirkusová 1740, 19300 Praha 9 - Horní Počernice \\ 3)Česká geologická služba, Geologická 6, 15200 Praha 5 \\ 4) Na Petřinách 1897, 16200 Praha 6
}

Pauliš P, Dolníček Z, VRtiška L, Malíková R, Pour O, Fediuk F (2021) Hydroxyapofylit-(K) z kamenolomu Těchlovice u Děčína (Česká republika). Bull Mineral Petrolog 29(1): 124-130 ISSN 2570-7337

\begin{abstract}
One xenolith of a contactly metamorphosed feldspar-hydroxyapophyllite hornfels from basaltic volcanite of the active quarry in Těchlovice village near-by the town of Děčín has been investigated. Its main components are represented by K-feldspar and hydroxyapophyllite-(K), which was hitherto reported from a single locality only in the territory of the Czech Republic. It forms grains up to $2 \mathrm{~mm}$ in size tightly associated with K-feldspar and subsidiary quartz, pyroxene (aegirine, enstatite-ferrosilite and diopside) and titanite. The unit cell parameters of hydroxyapophyllite-(K), derived from the powder $X$-ray data, are $a=8.975(4), c=15.8371(3) \AA$ and $V=1275.6(5) \AA^{3}$. Chemical analyses correspond to the empirical formula $\mathrm{K}_{0.93} \mathrm{Ca}_{375} \mathrm{Si}_{7.87} \mathrm{O}_{20}\left(\mathrm{OH}_{0.96} \mathrm{~F}_{0.04}\right) \cdot 8 \mathrm{H}_{2} \mathrm{O}$. The xenolith originated by a comparatively weak contact metamorphic effect of the basaltic magma to a marly sediment under high partial pressure of $\mathrm{H}_{2} \mathrm{O}$. Among xenoliths of North Bohemian Cainozoic volcanites the rock represents a rarity, which has not been known hitherto.
\end{abstract}

Key words: hydroxyapophyllite-(K), xenolite, powder X-ray diffraction data, unit-cell parameters, chemical composition, Cainozoic volcanics, Těchlovice near Děčín, Czech Republic

Obdrženo 6. 5. 2021; prijiato 24. 6. 2021

\section{Úvod}

Do skupiny apofylitu v současné době náleží šest minerálních fází: fluorapofylit-(Cs), fluorapofylit-(K), fluorapofylit-(Na), hydroxyapofylit-(K), hydroxymcglassonit-(K) a čerstvě popsaný fluorapofylit- $\left(\mathrm{NH}_{4}\right)$. V České republice patři apofylity $\mathrm{k}$ běžným minerálům. Nejvíce jsou zastoupeny $v$ efuzivech. Klasickou lokalitou je Mariánská hora $v$ Ústí nad Labem, kde se vyskytují až $2 \mathrm{~cm}$ velké krystaly, které jsou často albinizované (Dvořák et al. 2017). Krásné, bezbarvé, ale i jablečně zelené až $5 \mathrm{~cm}$ velké se vyskytovaly na vrchu Katzenkoppe (Kočičí hlava) u Velkého Března (Novák et al. 2001). Zajímavé vzorky pocházely též ze Starého vrchu u Radejčína, Puchavce u Provodína a z dalších míst. Vzácnější byl v melafyrech na Kozákově, v pegmatitech a samostatné žíle ve Vlastějovicích (Tvrdý 2000; Kadlec 2009); spolu se zeolity se vyskytl na hydrotermálních žilách na uranovém ložisku v Dolní Rožínce (Pauliš, Šikola 1999) a na alpských žilách v Markovicích u Čáslavi a Libodřicích u Kolína (Fišera et al. 2002). Všechny dosud známé apofylity z ČR, pokud byly analyzovány, je možné klasifikovat jako fluorapofylity-(K). Vzácnějším členem apofylitové skupiny je hydroxyapofylit-(K), který byl z ČR dosud exaktně zjištěn pouze ve výchozu komínové brekcie olivinického melilititu z jižního okraje Kytlic u Nového Boru, kde tvoří spolu s kalcitem a opálem bělavé hlízovité agregáty až $20 \mathrm{~cm}$ velké (Fediuk et al. 2004).
Studovaný hydroxyapofylit-(K) z Těchlovic je tedy jeho druhým ověřeným výskytem v ČR. Ostatní členy apofylitové skupiny, které jsou podstatně vzácnější, nebyly na našem území zjištěny.

\section{Geologie a mineralogie lokality}

První historické zmínky o těžbě kamene $v$ oblasti dnešních Těchlovic (něm. Tichlowitz, $7 \mathrm{~km}$ j. od Děčína) sahají až do druhé poloviny 17. století, kdy byla při těžbě využívána vodní energie Těchlovického potoka. Další zmínky se datují do druhé poloviny 19. století, kdy došlo počátkem 80. let ke znovuotevření starého lomu na z. svahu Holého vrchu (269 m n. m., něm. Kahler Berg) u Přední Lhoty (dnes součást Těchlovic), asi $500 \mathrm{~m} \mathrm{~s}$. od Těchlovic. V roce 1896 již bylo z lomů na Holém vrchu a z Dobkovic na protějším břehu Labe jen do Německa distribuováno 25.5 tisíc t kameniva (Radoň 2010). Těžba kamene tu probíhala i po 1. světové válce, kdy bylo ložisko využíváno drobnými těžaři. Vytěžený materiál byl dopravován po kolejích ke břehu Labe, odkud pokračoval jeho transport k zákazníkům po řece na lodích. Po 2. světové válce, až do roku 1948, byl lom v soukromém vlastnictví, po roce 1948 přešel do vlastnictví státu. V roce 1992 byl činný lom (obr. 1, 2) privatizován a převeden ze státního podniku Severokámen Liberec do soukromé sféry (Vildner 2010). 
V lomu se těží poměrně rozsáhlé těleso olivinického nefelinitu terciérního stáŕí, jehož pokračování z. směrem je odkryto opuštěným lomem v Dobkovicích. Labská eroze zde tuto intruzi prořízla. Podobně jako v Dobkovicích se i zde objevují petrograficky zajímavé žilné horniny - bostonit, gauteit, monchiquit a camptonit. Jak intruze olivinického nefelinitu, tak i tyto doprovodné žilné horniny jsou prostorově i geneticky spjaty s roztockou subvulkanickou strukturou. Pokryvné útvary jsou na ložisku zastoupeny svahovými hlínami a sutěmi, sprašemi a sprašovými hlínami. Hlíny a sutě dosahují mocnosti do 2 $\mathrm{m}$, ojediněle více. Podloží vulkanických hornin tvoří jílovce a prachovité pískovce s uhelnou príměsí. Teprve pod tímto bazálním terciérním souvrstvím následují kř́ídové sedimenty. Báze nefelinitové intruze směrem $\mathrm{k}$ západu klesá až na úroveň cca 140 m n. m. (Vildner 2010).

První mineralogické nálezy - čiré sloupečkovité krystaly natrolitu na analcimu - z této lokality zmiňuje již Reuss mladší (1840). První podrobný popis lokality provedli Hibsch (1899) a později Pelikan (1902). Popsali nálezy několika forem natrolitu, z nichž k nejzajímavějším patří prizmatické krystaly až 25 mm dlouhé, vyskytující se $v$ dutinách gauteitu. Zajímavé nálezy xenolitů přeměněných pískovců a slínů z čedičů studoval Cornu (1905). Pískovce byly přeměněny na tvrdý sklovitý buchit se sillimanitem a cordieritem, slínovce byly zeolitizovány natrolitem. Cornu (1907) se zmiňuje o drobných krystalech thomsonitu. Scheit (1912) popsal až $5 \mathrm{~mm}$ velké srůsty thomsonitu s natrolitem a až 2 $\mathrm{cm}$ velké krystaly analcimu a kalcit. Mineralogii lokality shrnuje Hibsch (1934). Zmiňuje klence kalcitu, natro-

Obr. 1 Pohled na kamenolom v Těchlovicích. Foto P. Pauliš (2020).

Obr. 2 Kamenolom v Těchlovicích, foceno $z$ horního patra, $v$ pozadí Labe a obec Dobkovice. Foto P. Pauliš (2020).

Obr. 3 Pohled na horní část kamenolomu Těchlovice, v pravé části je zachycena světlá partie xenolitu. Foto P. Pauliš (2020).
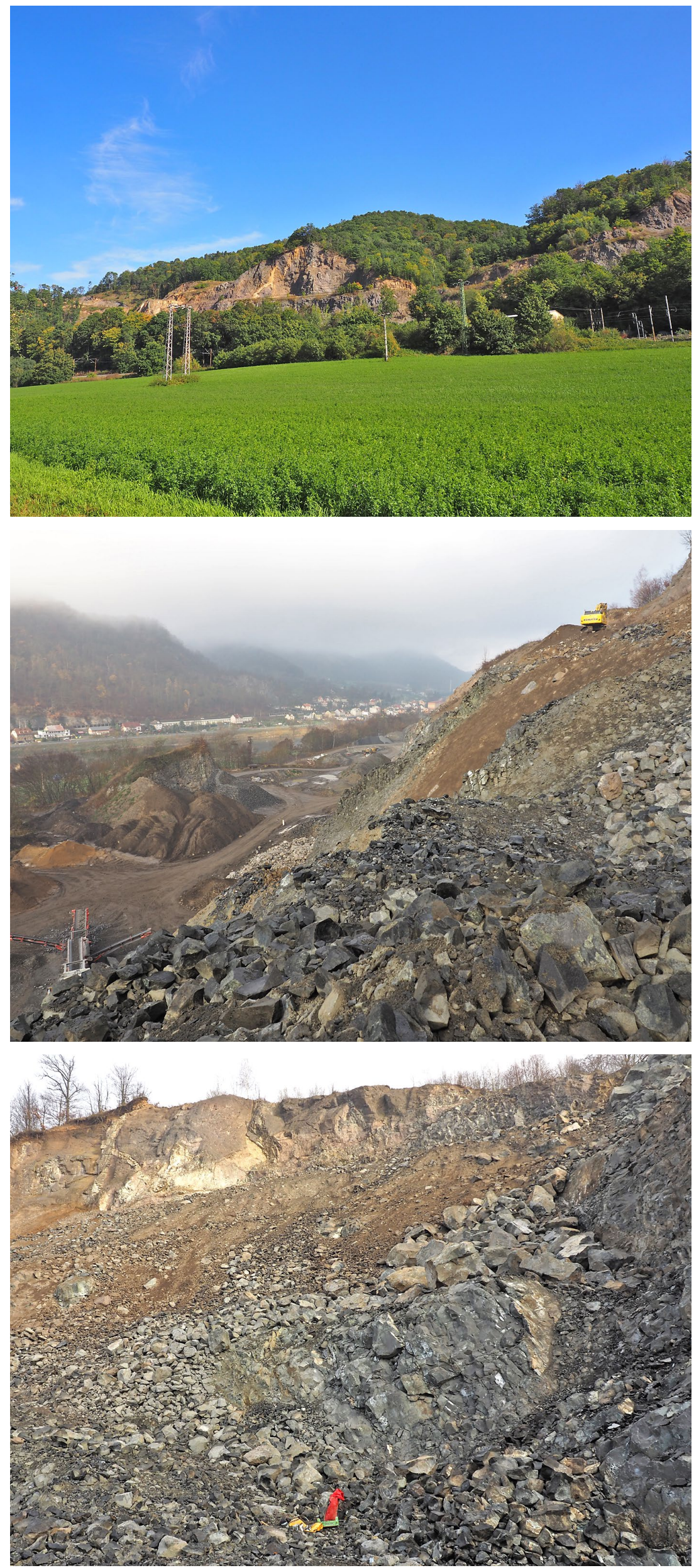


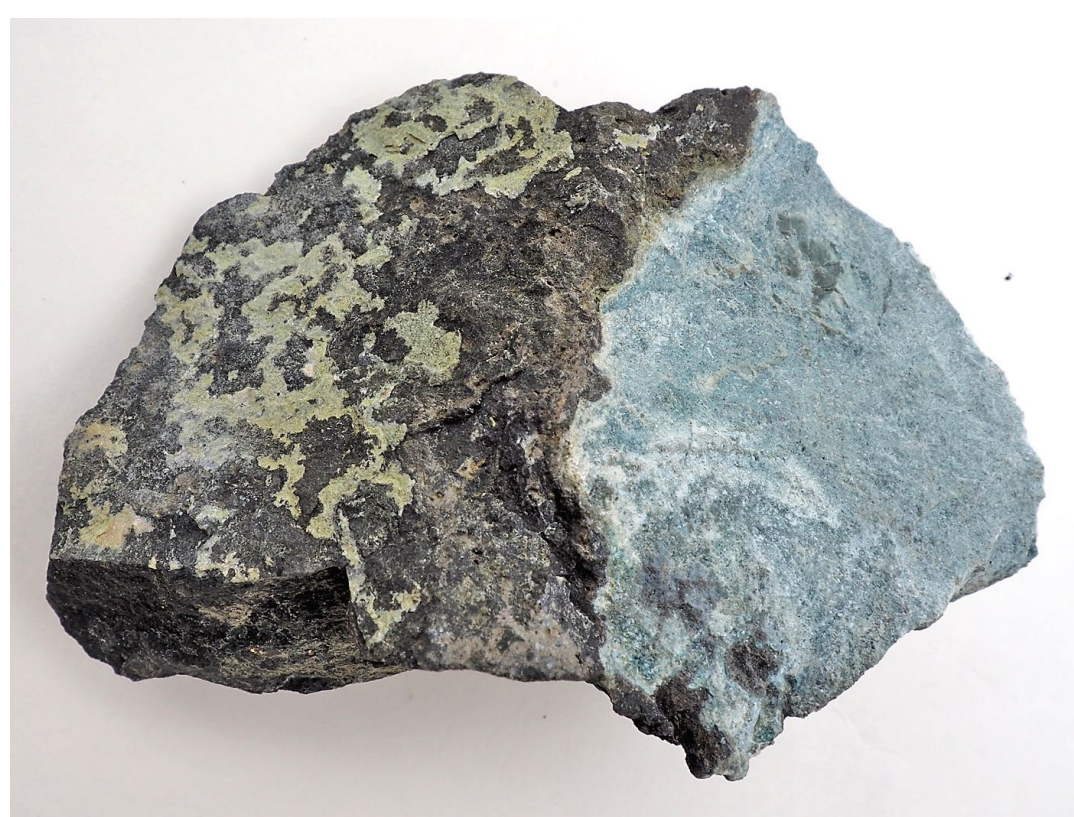

Obr. 4 Př́kontaktní část xenolitu, rozměry $13 \times 9 \mathrm{~cm}$. Foto P. Pauliš.

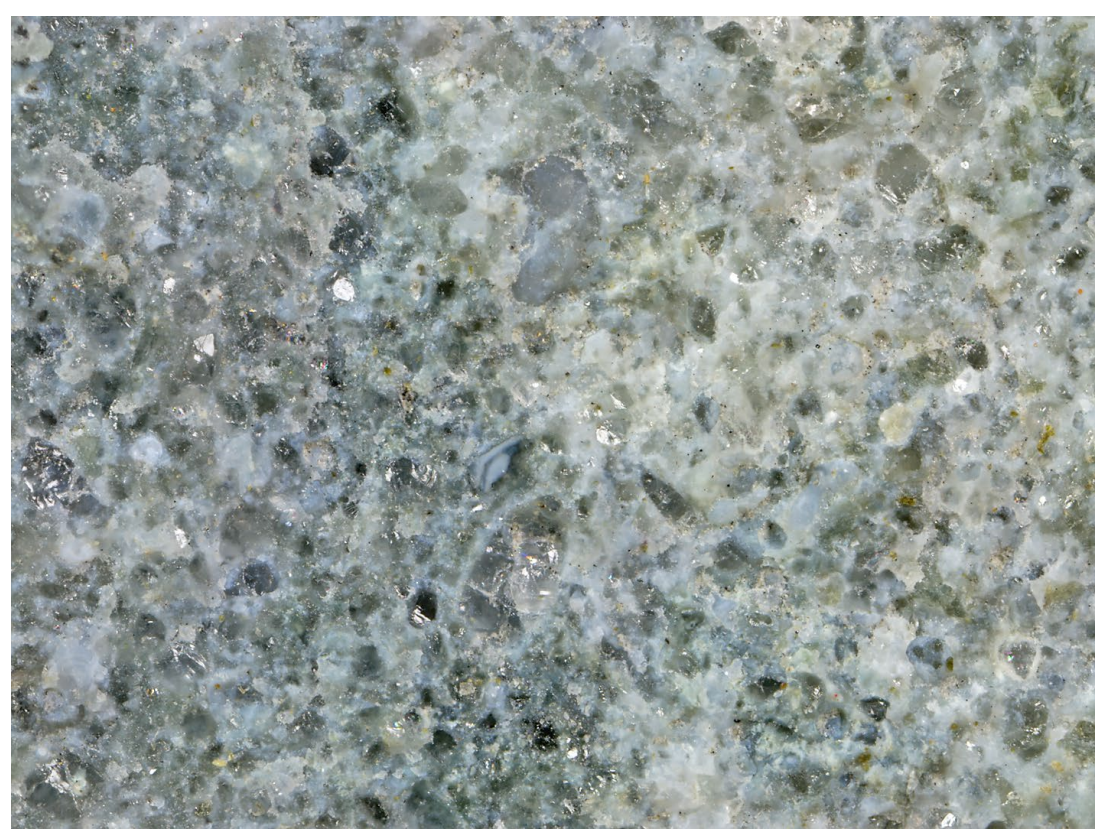

Obr. 5 Detailní část lomné plochy xenolitu, šířka záběru $6.8 \mathrm{~mm}$. Foto B. Bureš. lit a analcim. K výjimečným nálezům patřil zelenavý prehnit $s$ drobnými krystaly thomsonitu. V sedmdesátých letech minulého století, v období průzkumných prací, byly nacházeny bohaté agregáty analcimu, natrolitu a kalcitu se vzácnějším phillipsitem. Po obnovení těžby se Těchlovice staly nejbohatší lokalitou natrolitu a pektolitu v Českém středohoří. Krystaly natrolitu vyplňovaly až $40 \mathrm{~cm}$ velké dutiny. Jeho dokonale ukončené krystaly dosahovaly až $5 \mathrm{~cm}$ délky a $6 \mathrm{~mm}$ šírky. Podobně jako v lomu Dobkovice na protějším břehu Labe tu natrolit tvořil až několik $\mathrm{cm}$ mocné žíly. Spolu s ním se v dutinách žilných hornin vyskytovaly až několik $\mathrm{cm}$ velké krystaly thomsonitu. Nejzajímavějším nerostem této lokality je však radiálně paprsčitý, jemně vláknitý pektolit, jehož až $15 \mathrm{~cm}$ velké agregáty zcela vyplňovaly drobnější dutiny, ve větších se vyskytoval společně s natrolitem (Fišera 1985; Fengl et al. 1982). Spolu s těmito minerály se $v$ gauteitu objevovaly megakrysty kaersutitického amfibolu. Novák et al. (2004) odtud popsali celistvé agregáty saponitu.

\section{Metodika výzkumu}

Rentgenová prášková difrakční data byla získána pomocí práškového difraktometru Bruker D8 Advance (Národní muzeum, Praha) s polovodičovým pozičně citlivým detektorem LynxEye za užití CuKa záření (40 kV, 40 mA). Práškové preparáty byly naneseny $v$ acetonové suspenzi na nosič zhotovený z monokrystalu křemíku a následně pak byla pořízena difrakční data ve step-scanning režimu (krok $0.01^{\circ}$, načítací čas $8 \mathrm{~s} /$ krok detektoru, celkový čas experimentu cca 15 hod.). Pozice jednotlivých difrakčních maxim byly popsány

Tabulka 1 Rentgenová prášková data hydroxyapofylitu-(K) z Těchlovic

\begin{tabular}{rrrrrrrrrrrrrrrrrr}
\hline$h$ & $k$ & $l$ & $d_{\text {obs }}$ & \multicolumn{1}{c}{$l_{\text {obs }}$} & $d_{\text {calc }}$ & $h$ & $k$ & $l$ & \multicolumn{1}{c}{$d_{\text {obs }}$} & \multicolumn{1}{c}{$l_{\text {obs }}$} & $d_{\text {calc }}$ & $h$ & $k$ & $l$ & $d_{\text {obs }}$ & $l_{\text {obs }}$ & $d_{\text {calc }}$ \\
\hline 0 & 1 & 1 & 7.770 & 9 & 7.808 & 1 & 2 & 5 & 2.4863 & 5 & 2.4864 & 5 & 1 & 3 & 1.6701 & 4 & 1.6697 \\
1 & 1 & 0 & 6.332 & $<1$ & 6.346 & 2 & 3 & 1 & 2.4515 & 4 & 2.4589 & 2 & 5 & 1 & 1.6570 & 1 & 1.6574 \\
0 & 1 & 3 & 4.545 & 3 & 4.550 & 0 & 2 & 6 & 2.2772 & 4 & 2.2751 & 1 & 3 & 8 & 1.6242 & 1 & 1.6237 \\
0 & 2 & 0 & 4.468 & 3 & 4.487 & 2 & 1 & 6 & 2.2058 & $<1$ & 2.2053 & 1 & 5 & 4 & 1.6062 & $<1$ & 1.6083 \\
0 & 0 & 4 & 3.959 & 100 & 3.959 & 1 & 4 & 1 & 2.1576 & 2 & 2.1564 & 4 & 4 & 0 & 1.5872 & 6 & 1.5865 \\
1 & 2 & 1 & 3.877 & 4 & 3.891 & 3 & 1 & 5 & 2.1133 & 5 & 2.1137 & 3 & 2 & 8 & 1.5497 & $<1$ & 1.5494 \\
1 & 2 & 2 & 3.574 & 4 & 3.580 & 3 & 2 & 4 & 2.1072 & 1 & 2.1073 & 0 & 6 & 0 & 1.4974 & $<1$ & 1.4958 \\
2 & 2 & 0 & 3.163 & 6 & 3.173 & 0 & 0 & 8 & 1.9774 & 3 & 1.9796 & 2 & 5 & 5 & 1.4751 & $<1$ & 1.4749 \\
0 & 1 & 5 & 2.988 & 42 & 2.987 & 4 & 1 & 4 & 1.9123 & $<1$ & 1.9074 & 1 & 5 & 6 & 1.4650 & $<1$ & 1.4644 \\
2 & 2 & 2 & 2.946 & $<1$ & 2.945 & 4 & 2 & 4 & 1.7882 & $<1$ & 1.7900 & 1 & 6 & 2 & 1.4514 & $<1$ & 1.4504 \\
1 & 2 & 4 & 2.816 & $<1$ & 2.819 & 3 & 1 & 7 & 1.7699 & 1 & 1.7691 & 2 & 2 & 10 & 1.4169 & $<1$ & 1.4170 \\
1 & 3 & 1 & 2.795 & $<1$ & 2.794 & 1 & 5 & 1 & 1.7487 & $<1$ & 1.7493 & 5 & 4 & 2 & 1.3807 & 4 & 1.3801 \\
1 & 3 & 2 & 2.667 & 1 & 2.672 & 1 & 0 & 9 & 1.7270 & $<1$ & 1.7268 & 6 & 2 & 3 & 1.3699 & 4 & 1.3704 \\
3 & 0 & 3 & 2.600 & $<1$ & 2.603 & & & & & & & & & & &
\end{tabular}


profilovou funkcí Pseudo-Voigt a upřesněny profilovým fitováním v programu HighScore Plus. Mř́žkové parametry byly zpřesněny metodou nejmenších čtverců pomocí programu Celref (Laugier, Bochu 2011).

Chemické složení silikátů bylo kvantitativně studováno pomocí elektronového mikroanalyzátoru Cameca SX100 (Národní muzeum, Praha, analytik Z. Dolníček) za podmínek: vinově disperzní analýza, napětí $15 \mathrm{kV}$, proud $10 \mathrm{nA}$ (pyroxeny, K-živec, titanit), respektive $5 \mathrm{nA}$ (hydroxyapofylit-K), průměr svazku $2 \mu \mathrm{m}$ (pyroxeny, K-živec, titanit), respektive $5 \mu \mathrm{m}$ (hydroxyapofylit -K). V pyroxenech byly stanovovány obsahy $\mathrm{Al}, \mathrm{Ba}, \mathrm{Ca}, \mathrm{Cl}, \mathrm{Cu}, \mathrm{F}, \mathrm{Fe}, \mathrm{K}$, $\mathrm{Mg}, \mathrm{Mn}, \mathrm{N}, \mathrm{Na}, \mathrm{Ni}, \mathrm{P}, \mathrm{S}, \mathrm{Sr}, \mathrm{Ti}, \mathrm{V}$ a Zn, $v$ hydroxyapofylitu-K byly měřeny $\mathrm{Al}$, $\mathrm{Ba}, \mathrm{Ca}, \mathrm{Cl}, \mathrm{F}, \mathrm{Fe}, \mathrm{K}, \mathrm{Mg}, \mathrm{Mn}, \mathrm{N}, \mathrm{Na}$, $\mathrm{P}, \mathrm{Pb}, \mathrm{Rb}, \mathrm{S}, \mathrm{Si}, \mathrm{Sr}$ a Zn, v K-živci Al, $\mathrm{Ba}, \mathrm{Ca}, \mathrm{Cs}, \mathrm{Cu}, \mathrm{Fe}, \mathrm{K}, \mathrm{Mg}, \mathrm{Mn}, \mathrm{N}$, $\mathrm{Na}, \mathrm{P}, \mathrm{Pb}, \mathrm{Rb}, \mathrm{Si}, \mathrm{Sr}$ a $\mathrm{Zn}, \mathrm{v}$ titanitu $\mathrm{Al}, \mathrm{Ca}, \mathrm{Ce}, \mathrm{F}, \mathrm{Fe}, \mathrm{La}, \mathrm{Mg}, \mathrm{Mn}, \mathrm{Na}, \mathrm{Nb}$, $\mathrm{Nd}, \mathrm{P}, \mathrm{Pr}, \mathrm{Sc}, \mathrm{Si}, \mathrm{Sr}$, Ta, Ti, Y a Zr. Při analýzách byly využity následující standardy a analytické čáry: baryt $(\mathrm{Ba} L \alpha)$, albit $(\mathrm{NaK} \alpha)$, sanidin (AlKa, SiKa, $K K \alpha)$, rodonit $(\mathrm{MnK} \alpha)$, diopsid $(\mathrm{Mg} K \alpha), \mathrm{TiO}_{2}(\mathrm{Ti} K \alpha)$, apatit $(\mathrm{PK} \alpha)$, halit $(\mathrm{ClK} \alpha)$, hematit $(\mathrm{Fe} K \alpha), \mathrm{ZnO}$ $(\mathrm{ZnK} \alpha), \mathrm{Cr}_{2} \mathrm{O}_{3}(\mathrm{Cr} K \alpha)$, celestin ( $\mathrm{S} K \alpha$, $\mathrm{Sr} L \beta)$, vanadinit $(\mathrm{V} K \alpha)$, wollastonit $(\mathrm{CaK} \alpha), \mathrm{CePO}_{4}(\mathrm{Ce} K \alpha), \mathrm{YPO}_{4}(\mathrm{YK} \alpha)$, $\mathrm{LaPO}_{4}(\mathrm{LaK} \alpha), \mathrm{NdPO}_{4}(\mathrm{NdK \alpha}), \mathrm{PrPO}_{4}$ $(\mathrm{PrK} \alpha), \mathrm{YVO}_{4}(\mathrm{YK} \alpha)$, zirkon $(\mathrm{ZrK \alpha}) \mathrm{a}$ LiF $(F K \alpha)$. Získaná data byla přepočítána na hm. \% oxidů za použití algoritmu PAP (Pouchou, Pichoir 1985). Výsledky byly korigovány na koincidence $\mathrm{Ca}-\mathrm{P}, \mathrm{Ce}-\mathrm{F}, \mathrm{Ba}-\mathrm{Ti}, \mathrm{Ti}-\mathrm{V}$. Obsahy měřených prvků, které nejsou uvedeny $v$ níže prezentovaných tabulkách minerálních analýz, byly ve všech prípadech pod mezí stanovitelnosti, která se pohybovala nejčastěji mezi $0.05-0.1 \mathrm{hm}$. \%.

\section{Petrografická a mineralogická charakteristika xenolitu}

Na podzim 2020 byly prvním autorem této studie nalezeny na středním patře jižní části činného kamenolomu Těchlovice (GPS: 5042'24.426“N;

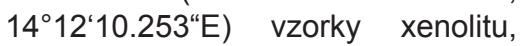
které byly nápadné svojí světle šedozelenou barvou. Xenolit, který byl odkryt ve stěně lomu, tvoří vertikálně uloženou nepravidelnou uzavřeninu o rozměrech cca $200 \times 60 \mathrm{~cm}$ (obr. $3)$. Jeho fragmenty se též nacházely $v$ suti čerstvě odstřeleného materiálu. Xenolitová hmota není zcela homogenní, převažující světle šedozelené partie střídají světle šedé a bělavé, s kontaktní plochou více či méně paralelní polohy. $\mathrm{V}$ detailu se xeno- litová hmota skládá zhruba z menší poloviny z nepřiliš nápadných krupičkovitých drobných porfyroblastů bělavé barvy o velikosti maximálně $2 \mathrm{~mm}$. Uzavírá je bledě šedá základní hmota o zrnech rozměrů zcela pod hranicí makroskopické rozlišitelnosti. Rozmístění těchto bledých

Tabulka 2 Parametry základní cely hydroxyapofylitu-(K) (pro tetragonální prostorovou grupu $\mathrm{P} 4 / \mathrm{mnc}$ )

\begin{tabular}{rcc}
\hline & tato práce & Rouse et al. (1978) \\
\hline$a[\AA]$ & $8.975(4)$ & $8.978(3)$ \\
$c[\AA]$ & $15.8371(3)$ & $15.83(1)$ \\
$V\left[\AA^{3}\right]$ & $1275.6(5)$ & 1275,97 \\
\hline
\end{tabular}

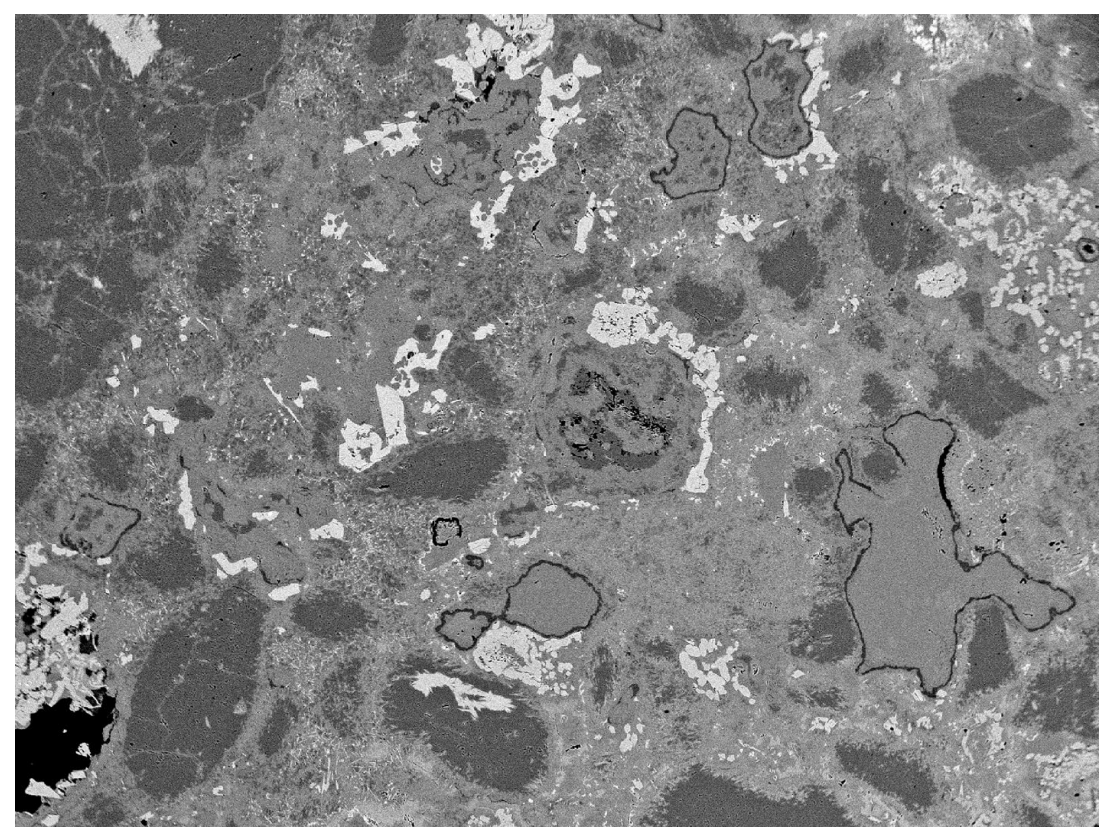

Obr. 6 Nepravidelná zrna hydroxyapofylitu-(K) (tmavošedá) s úzkým lemem K-živce (šedočerný) srůstající s agregáty křemene (černošedá), pyroxenů (světle šedá) a jemnozrnné křemen-živcové hmoty (středně šedá); Těchlovice; šiřka záběru $2.4 \mathrm{~mm}$, foto v BSE Z. Dolníček.

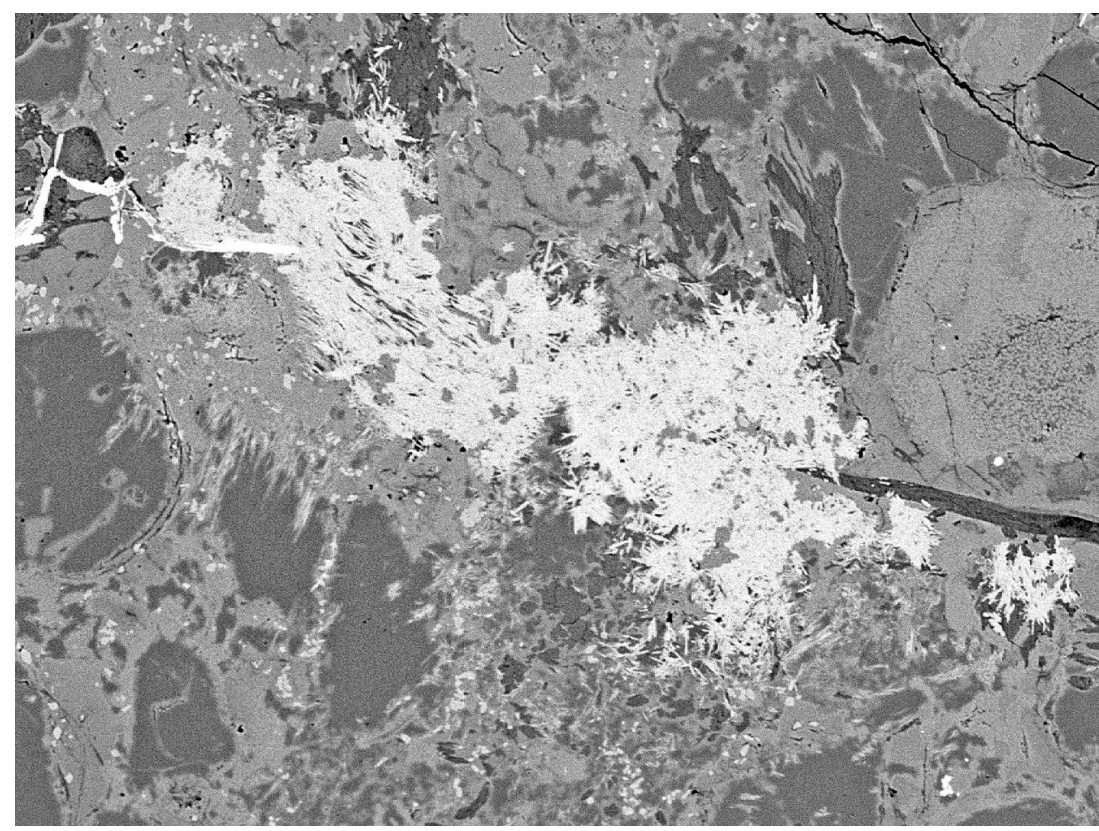

Obr. 7 Agregát jehličkovitého egirinu (světle šedý) se zrny křemene (černošedý) a K-živcem (středně šedý); šírka záběru $0.85 \mathrm{~mm}$, foto v BSE Z. Dolníček. 
zrn je značně nerovnoměrné, místy vytvářejí závojovité pruhy. Odebraný vzorek pro petrografické studium zastihuje v úzkém odlomu kontakt s uzavírajícím bazaltoidem. Ten je téměř sytě černé barvy. $V$ jeho velmi jemnozrnné hmotě Ize rozeznat singulární drobné vyrostlice patrně olivínu a hojné, nepř́liš však nápadné drobné dutinky izometrických tvarů. Styk bazaltoidu s xenolitem je zcela ostrý (obr. 4).

Podle mikroskopického rozboru z provedeného výbrusu se na složení xenolitu podílejí tyto minerály (přibližný odhad procentuálního zastoupení je uveden v závorce): apofylit (45), živec (50) a limonit (5). Apofylit vystupuje $\checkmark$ podobě bezbarvých individualizovaných zrn vzhledově připomínajících porfyroblasty. Jsou víceméně izometrického a hypautomorfně omezeného habitu, rozměrově značně kolísají v desetinách $\mathrm{mm}$. Opticky se vyznačuje nízkým indexem lomu, nízkým dvojlomem a zřetelnou štěpností. Minerálem poněkud četněji zastoupeným je živec. Vesměs je omezen xenomorfně a vždy je alteračně zkalen. Dvojčatné srůsty nebo mřižkování nejsou patrny. Podle nízkého indexu lomu jde o K-živec. Se značným kvantitativním odstupem se jako třetí minerální součástka horniny uplatňuje limonit. Disperzně a místy shlukově prostupuje draselným živcem, nikdy ne apofylitem.

Tabulka 3 Chemické složení hydroxyapofylitu-(K) z Těchlovic (hm. \%)

\begin{tabular}{lrrrrrrr}
\hline & mean & 1 & 2 & 3 & 4 & 5 & 6 \\
\hline $\mathrm{SiO}_{2}$ & 52.78 & 53.20 & 52.82 & 53.42 & 52.10 & 53.41 & 51.76 \\
$\mathrm{CaO}$ & 23.47 & 22.63 & 23.39 & 23.67 & 23.78 & 23.47 & 23.87 \\
$\mathrm{~K}_{2} \mathrm{O}$ & 5.07 & 5.47 & 4.94 & 4.98 & 5.00 & 5.06 & 4.96 \\
$\mathrm{~F}$ & 0.08 & 0.03 & 0.15 & 0.00 & 0.04 & 0.16 & 0.09 \\
$\mathrm{H}_{2} \mathrm{O}$ & 16.77 & 16.93 & 16.75 & 17.01 & 16.57 & 16.93 & 16.44 \\
\hline total & 98.17 & 98.26 & 98.05 & 99.08 & 97.50 & 99.04 & 97.12 \\
\hline $\mathrm{Si}^{4+}$ & 8.000 & 8.000 & 8.000 & 8.000 & 8.000 & 8.000 & 8.000 \\
$\mathrm{Ca}^{2+}$ & 3.812 & 3.646 & 3.796 & 3.798 & 3.913 & 3.767 & 3.953 \\
$\mathrm{~K}^{+}$ & 0.980 & 1.049 & 0.955 & 0.951 & 0.979 & 0.967 & 0.978 \\
$\mathrm{~F}^{-}$ & 0.038 & 0.014 & 0.072 & 0.000 & 0.019 & 0.076 & 0.044 \\
$\mathrm{OH}^{-}$ & 0.962 & 0.986 & 0.928 & 1.000 & 0.981 & 0.924 & 0.956 \\
$\mathrm{H}_{2} \mathrm{O}$ & 8 & 8 & 8 & 8 & 8 & 8 & 8 \\
\hline
\end{tabular}

Empirický vzorec byl přepočten na bázi 8 atomů Si. $\mathrm{H}_{2} \mathrm{O}$ bylo dopočítáno na základě teoretického obsahu $8 \mathrm{H}_{2} \mathrm{O}$ a $\mathrm{Fe}+\mathrm{OH}=1$.

Tabulka 4 Chemické složení K-živce z Těchlovic (hm. \%)

\begin{tabular}{lrrrrr}
\hline & mean & 1 & 2 & 3 & 4 \\
\hline $\mathrm{SiO}_{2}$ & 64.89 & 65.08 & 64.43 & 64.68 & 65.37 \\
$\mathrm{Al}_{2} \mathrm{O}_{3}$ & 17.77 & 17.70 & 17.66 & 18.19 & 17.54 \\
$\mathrm{SrO}$ & 0.13 & 0.11 & 0.15 & 0.07 & 0.18 \\
$\mathrm{BaO}$ & 0.08 & 0.04 & 0.12 & 0.12 & 0.03 \\
$\mathrm{~K}_{2} \mathrm{O}$ & 16.43 & 16.89 & 16.13 & 16.06 & 16.63 \\
$\mathrm{Na}_{2} \mathrm{O}$ & 0.31 & 0.32 & 0.46 & 0.42 & 0.04 \\
\hline total & 99.61 & 100.14 & 98.95 & 99.54 & 99.79 \\
\hline $\mathrm{Si}^{4+}$ & 3.021 & 3.020 & 3.019 & 3.008 & 3.031 \\
$\mathrm{Al}^{3+}$ & 0.977 & 0.968 & 0.975 & 0.997 & 0.958 \\
$\mathrm{Sr}^{2+}$ & 0.001 & 0.001 & 0.004 & 0.002 & 0.005 \\
$\mathrm{Ba}^{2+}$ & 0.001 & 0.001 & 0.002 & 0.002 & 0.001 \\
$\mathrm{~K}^{+}$ & 0.976 & 1.000 & 0.964 & 0.953 & 0.983 \\
$\mathrm{Na}^{+}$ & 0.011 & 0.011 & 0.016 & 0.015 & 0.002 \\
\hline
\end{tabular}

Empirický vzorec byl přepočten na bázi 8 kyslíků.
Strukturu horniny Ize klasifikovat jako drobně porfyroblastickou, textura kolísá od všesměrné po paralelní. Jde o apofylit-živcový kontaktní rohovec, vzniklý patrně relativně slabým kontaktně metamorfním účinkem bazaltoidního magmatu ze sedimentu slínové povahy za vysokého parciálního tlaku $\mathrm{H}_{2} \mathrm{O}$. Mezi hojnými xenolity v severočeských kenozoických vulkanitech jde o pozoruhodný nález.

Mikroskopický obraz příkontaktního vulkanitu, který je zastižen plochou výbrusu, potvrzuje jeho slabou porfyričnost. Drobné vyrostlice klinopyroxenu a olivínu, alteracemi jen slabě postiženému, rozhodně nejsou jeho markantem, hornina má téměř afyrickou povahu. $V$ její hmotě jsou obsaženy hojné drobné plagioklasové lišty a

Tabulka 5 Chemické složení titanitu z Těchlovic (hm. \%)

\begin{tabular}{lrrrrr}
\hline & mean & 1 & 2 & 3 & 4 \\
\hline $\mathrm{SiO}_{2}$ & 30.43 & 30.51 & 30.59 & 30.24 & 30.37 \\
$\mathrm{TiO}_{2}$ & 28.24 & 27.43 & 25.58 & 30.08 & 29.88 \\
$\mathrm{Al}_{2} \mathrm{O}_{3}$ & 0.15 & 0.20 & 0.26 & 0.01 & 0.15 \\
$\mathrm{La}_{2} \mathrm{O}_{3}$ & 0.08 & 0.07 & 0.07 & 0.11 & 0.08 \\
$\mathrm{Ce}_{2} \mathrm{O}_{3}$ & 0.18 & 0.20 & 0.19 & 0.17 & 0.16 \\
$\mathrm{P}_{2} \mathrm{O}_{5}$ & 2.21 & 2.71 & 2.43 & 2.02 & 1.68 \\
$\mathrm{MgO}$ & 0.64 & 0.54 & 1.01 & 0.51 & 0.51 \\
$\mathrm{CaO}$ & 25.42 & 25.17 & 24.58 & 25.75 & 25.64 \\
$\mathrm{FeO}$ & 5.09 & 3.97 & 6.51 & 4.94 & 4.93 \\
$\mathrm{Na}_{2} \mathrm{O}$ & 0.72 & 0.74 & 0.82 & 0.68 & 0.65 \\
\hline total & 92.44 & 91.68 & 92.04 & 94.59 & 94.05 \\
\hline $\mathrm{Si}^{4+}$ & 1.000 & 1.012 & 1.027 & 0.977 & 0.986 \\
$\mathrm{Ti}^{4+}$ & 0.872 & 0.856 & 0.808 & 0.914 & 0.912 \\
$\mathrm{Al}^{3+}$ & 0.006 & 0.008 & 0.010 & 0.001 & 0.006 \\
$\mathrm{La}^{3+}$ & 0.001 & 0.001 & 0.001 & 0.001 & 0.002 \\
$\mathrm{Ce}^{3+}$ & 0.002 & 0.002 & 0.002 & 0.002 & 0.002 \\
$\mathrm{P}^{5+}$ & 0.062 & 0.076 & 0.069 & 0.055 & 0.046 \\
$\mathrm{Mg}^{2+}$ & 0.031 & 0.027 & 0.051 & 0.025 & 0.025 \\
$\mathrm{Ca}^{2+}$ & 0.895 & 0.913 & 0.884 & 0.892 & 0.892 \\
$\mathrm{Fe}^{2+}$ & 0.140 & 0.110 & 0.183 & 0.134 & 0.134 \\
$\mathrm{Na}^{+}$ & 0.046 & 0.047 & 0.053 & 0.043 & 0.041 \\
\hline $\mathrm{Emp}^{2+}$ & & & & &
\end{tabular}

Empirický vzorec byl přepočten na bázi 5 kyslíků.

Tabulka 6 Chemické složení egirinu z Těchlovic (hm. \%)

\begin{tabular}{lrrrrrr}
\hline & 1 & 2 & 3 & 4 & 5 & 6 \\
\hline $\mathrm{SiO}_{2}$ & 51.42 & 51.09 & 52.48 & 52.97 & 52.48 & 52.02 \\
$\mathrm{TiO}_{2}$ & $2 ., 06$ & 2.86 & 3.75 & 2.52 & 3.09 & 2.71 \\
$\mathrm{Fe}_{2} \mathrm{O}_{3}$ & 28.82 & 28.97 & 27.97 & 28.26 & 26.47 & 27.27 \\
$\mathrm{MgO}$ & 1.24 & 0.97 & 1.04 & 2.41 & 3.07 & 2.66 \\
$\mathrm{MnO}$ & 0.62 & 0.37 & 0.31 & 0.03 & 0.08 & 0.04 \\
$\mathrm{CaO}$ & 1.12 & 0.55 & 0.53 & 0.94 & 0.95 & 0.83 \\
$\mathrm{SrO}$ & 0.17 & 0.15 & 0.18 & 0.20 & 0.20 & 0.32 \\
$\mathrm{Na}_{2} \mathrm{O}$ & 12.52 & 13.00 & 13.56 & 12.98 & 13.11 & 12.46 \\
\hline total & 97.97 & 97.96 & 99.82 & 99.37 & 99.45 & 98.31 \\
\hline $\mathrm{Si}^{4+}$ & 1.989 & 1.973 & 1.971 & 1.987 & 1.982 & 1.987 \\
$\mathrm{Ti}^{4+}$ & 0.075 & 0.104 & 0.132 & 0.089 & 0.109 & 0.097 \\
$\mathrm{Fe}^{3+}$ & 0.839 & 0.842 & 0.790 & 0.780 & 0.752 & 0.784 \\
$\mathrm{Mg}^{2+}$ & 0.072 & 0.055 & 0.058 & 0.135 & 0.173 & 0.151 \\
$\mathrm{Mn}^{2+}$ & 0.020 & 0.012 & 0.010 & 0.001 & 0.002 & 0.001 \\
$\mathrm{Ca}^{2+}$ & 0.047 & 0.022 & 0.042 & 0.038 & 0.038 & 0.034 \\
$\mathrm{Sr}^{2+}$ & 0.004 & 0.003 & 0.004 & 0.004 & 0.004 & 0.007 \\
$\mathrm{Na}^{+}$ & 0.939 & 0.973 & 0.987 & 0.944 & 0.960 & 0.923 \\
\hline
\end{tabular}

Empirický vzorec byl přepočten na bázi 6 kyslíků. 
rovněž drobný, převážně krátce prizmatický až izometricky zrnitý klinopyroxen. Toto základní minerální složení doplňují v podílu do $10 \%$ izometrická zrníčka magnetitu. Podílem zcela podružným se uplatňují xenomorfní zrna bezbarvého, slabě dvojlomného až izotropního minerálu, jímž může být nefelín. Struktura horniny je velmi slabě porfyrická až afyrická, pilotaxitická, textura je silně dutinatá, paralelní. Jde o slabě olivinický bazalt, téměř afyrický, se slabou tefritickou afinitou.

Rentgenová prášková analýza vzorku xenolitu z Těchlovic potvrdila dominantní obsahy K-živce a apofylitu, který byl na základě provedených chemických analýz identifikován jako hydroxyapofylit-(K) a dále zachytila minoritní obsah křemene a diopsidu. $\mathrm{V}$ hornině tvoří až $2 \mathrm{~mm}$ velká, skelně lesklá nepravidelná zrna (obr. 5). Jeho rentgenová prášková data (tab. 1) jsou blízká da-

Tabulka 7 Chemické složení enstatit-ferosilitu (hypersten) z Těchlovic (hm. \%)

\begin{tabular}{lrrrrr}
\hline & 1 & 2 & 3 & 4 & 5 \\
\hline $\mathrm{SiO}_{2}$ & 51.90 & 51.33 & 51.64 & 50.38 & 50.76 \\
$\mathrm{TiO}_{2}$ & 0.27 & 0.88 & 0.28 & 0.16 & 0.48 \\
$\mathrm{Al}_{2} \mathrm{O}_{3}$ & 0.69 & 0.54 & 0.81 & 0.80 & 0.70 \\
$\mathrm{MgO}$ & 19.66 & 16.18 & 19.26 & 15.87 & 14.72 \\
$\mathrm{CaO}$ & 3.62 & 3.12 & 3.67 & 5.29 & 4.61 \\
$\mathrm{FeO}$ & 22.69 & 21.64 & 22.70 & 25.44 & 24.75 \\
$\mathrm{MnO}$ & 0.44 & 0.35 & 0.43 & 0.34 & 0.37 \\
$\mathrm{Na}_{2} \mathrm{O}$ & 0 & 1.88 & 0 & 0.29 & 1.31 \\
\hline total & 99.27 & 95.92 & 98.79 & 98.57 & 97.70 \\
\hline $\mathrm{Si}^{4+}$ & 1.969 & 2.014 & 1.970 & 1.967 & 1.993 \\
$\mathrm{Ti}^{4+}$ & 0.010 & 0.033 & 0.020 & 0.006 & 0.018 \\
$\mathrm{Al}^{3+}$ & 0.031 & 0.025 & 0.036 & 0.037 & 0.033 \\
$\mathrm{Mg}^{2+}$ & 1.112 & 0.946 & 1.095 & 0.924 & 0.862 \\
$\mathrm{Ca}^{2+}$ & 0.147 & 0.131 & 0.150 & 0.221 & 0.194 \\
$\mathrm{Fe}^{2+}$ & 0.720 & 0.710 & 0.724 & 0.831 & 0.813 \\
$\mathrm{Mn}^{2+}$ & 0.014 & 0.012 & 0.014 & 0.011 & 0.012 \\
$\mathrm{Na}^{+}$ & 0 & 0.143 & 0 & 0.022 & 0.099 \\
\hline $\mathrm{Empirický}^{2+}$ vzorec byl přepočten na bázi 6 kyslíků.
\end{tabular}

Empirický vzorec byl přepočten na bázi 6 kyslíků.

Tabulka 8 Chemické složení diopsidu z Těchlovic (hm. \%)

\begin{tabular}{lrrr}
\hline & 1 & 2 & 3 \\
\hline $\mathrm{SiO}_{2}$ & 50.37 & 50.47 & 51.61 \\
$\mathrm{TiO}_{2}$ & 0.64 & 0.63 & 0.60 \\
$\mathrm{Al}_{2} \mathrm{O}_{3}$ & 4.09 & 4.06 & 4.20 \\
$\mathrm{Cr}_{2} \mathrm{O}_{3}$ & 0.73 & 0.68 & 0.73 \\
$\mathrm{MgO}$ & 15.35 & 16.17 & 16.03 \\
$\mathrm{CaO}$ & 20.02 & 20.94 & 20.91 \\
$\mathrm{FeO}$ & 5.70 & 4.17 & 4.27 \\
$\mathrm{Na}_{2} \mathrm{O}$ & 0.44 & 0.63 & 0.69 \\
\hline total & 97.34 & 97.75 & 99.04 \\
\hline $\mathrm{Si}^{4+}$ & 1.862 & 1.893 & 1.880 \\
$\mathrm{Ti}^{4+}$ & 0.002 & 0.002 & 0.002 \\
$\mathrm{Al}^{3+}$ & 0.178 & 0.179 & 0.180 \\
$\mathrm{Cr}^{3+}$ & 0.021 & 0.020 & 0.021 \\
$\mathrm{Mg}^{2+}$ & 0.846 & 0.904 & 0.871 \\
$\mathrm{Ca}^{2+}$ & 0.793 & 0.841 & 0.816 \\
$\mathrm{Fe}^{2+}$ & 0.176 & 0.131 & 0.130 \\
$\mathrm{Na}^{+}$ & 0.032 & 0.046 & 0.049 \\
\hline
\end{tabular}

Empirický vzorec byl přepočten na bázi 6 kyslíků. tům pro tento minerální druh, zpřesněné parametry základní cely dobře odpovídají publikovaným údajům (tab. 2). V nábrusu je mikroskopický obraz xenolitové hmoty poměrně komplikovaný, vedle uvedených dvou hlavních minerálních složek jsou přítomny $v$ menším množství křemen a další silikátové minerály. $V$ BSE obraze je hydroxyapofylit-(K) poměrně homogenní. $V$ nábrusu tvoři nepravidelná, někdy laločnatě členěná zrna velikosti do $0.5 \mathrm{~mm}$, která bývají úzce lemována K-živcem (obr. 6). Těsně asociuje s K-živcem, křemenem a pyroxeny. Při studiu jeho chemického složení byly zjištěny obsahy $\mathrm{Si}$, $\mathrm{Ca}, \mathrm{K}$ a $\mathrm{F}$; ostatní měřené prvky byly pod mezí detekce (tab. 3). Obsahuje jen nepatrné množství fluoru $(0.038$ apfu). Jeho empirický vzorec (průměr šest bodových analýz) je na bázi 20 atomů kyslíku možno vyjádřit jako $\mathrm{K}_{0.93} \mathrm{Ca}_{3.75} \mathrm{Si}_{7.87} \mathrm{O}_{20}\left(\mathrm{OH}_{0.96} \mathrm{~F}_{0.04}\right) \cdot 8 \mathrm{H}_{2} \mathrm{O}$. Další složkou, která $v$ ploše nábrusu dominuje, je K-živec, který tvoří nejčastěji oválná zrna velikosti do $0.5 \mathrm{~mm}$. Při studiu jeho chemického složení byly zjištěny obsahy $\mathrm{Si}, \mathrm{Al}, \mathrm{K}$, v malé míre $\mathrm{Na}$ (0.011 apfu), Sr (0.001 apfu) a Ba (0.001 apfu); ostatní měřené prvky byly pod mezí detekce (tab. 4). Jeho empirický vzorec (průměr čtyř bodových analýz) je na bázi osmi atomů kyslíku možno vyjádřit jako $\mathrm{K}_{0.98} \mathrm{Na}_{0.01}$ $\mathrm{Si}_{302} \mathrm{Al}_{0.98} \mathrm{O}_{8}$. S K-živcem na některých místech srůstaji až $0.5 \mathrm{~mm}$ velká oválná zrna křemene. $V$ akcesorickém množství byl $v$ nábruse zjištěn železem bohatý titanit, který tvoří v ploše nábrusu laločnatá zrna o rozměrech $100-150 \mu \mathrm{m}$. Při studiu jeho chemického složení byly zjištěny obsahy $\mathrm{Si}, \mathrm{Ti}, \mathrm{Ca}, \mathrm{Fe}, \mathrm{P}$ a v malé míře i $\mathrm{Na}, \mathrm{Mg}$, $\mathrm{Al}$, La a Ce, ostatní měřené prvky byly pod mezí detekce (tab. 5). Vedle hlavních složek $\left(\mathrm{SiO}_{2}, \mathrm{TiO}_{2}\right.$ a $\left.\mathrm{CaO}\right)$ obsahuje poměrně vysoké obsahy Fe $(0.110-0.183$ apfu) a $\mathrm{P}$ (0.046 - $0.076 a p f u$ ). Jeho empirický vzorec (průměr čtyř bodových analýz) je na bázi pěti atomů kyslíku možno vyjádřit jako $\mathrm{Ca}_{0.90} \mathrm{Na}_{0.05} \mathrm{Fe}_{0.14} \mathrm{Mg}_{0.03} \mathrm{Ti}_{0.87} \mathrm{P}_{0.06} \mathrm{Si}_{1.00} \mathrm{O}_{5.00}$. Dalšími akcesorickými složkami, které byly mikroskopicky zjištěny $v$ xenolitové hmotě, jsou pyroxeny. Na základě chemického složení (tab. 6 - 8) Ize v nábrusech rozlišit pyroxeny blízké egirinu, enstatit-ferosilitu (hypersten) a diopsidu. Nejčastější je egirin, tvořící až $1 \mathrm{~mm}$ velké agregáty $10-20 \mu \mathrm{m}$ dlouhých jehliček (obr. 7). Diopsid tvoří oválná či nepravidelně laločnatá, až $100 \mu \mathrm{m}$ velká zrna. Vedle těchto identifikovaných minerálních složek obsahuje tento xenolit velmi jemnozrnnou směsnou silikátovou hmotu, která nebyla detailněji studována.

\section{Závěr}

Nově zjištěný xenolit $v$ bazaltech těžených kamenolomem $v$ Těchlovicích je tvořen zajímavou minerální asociací s hydroxyapofylitem-(K), který byl v ČR dosud potvrzen pouze na jedné lokalitě. $\mathrm{V}$ xenolitu tvoří až 2 $\mathrm{mm}$ velká zrna těsně asociující $\mathrm{s} K$ K-živcem a podřadně zastoupenými dalšími fázemi - křemenem, pyroxeny a titanitem. Jde o apofylit-živcový kontaktní rohovec, vzniklý patrně relativně slabým kontaktně metamorfním účinkem bazaltoidního magmatu ze sedimentu slínové povahy, za vysokého parciálního tlaku $\mathrm{H}_{2} \mathrm{O}$. Mezi xenolity severočeských kenozoických vulkanitů jde o výjimečný nález, který zde dosud nebyl zjištěn.

\section{Poděkování}

Milou povinností autorů je poděkovat za detailní fotografii lomné plochy xenolitu B. Burešovi z Prahy. Předložená práce vznikla za finanční podpory Ministerstva kultury ČR v rámci institucionálního financování výzkumné organizace Národní muzeum (00023272 - cíl DKRVO 1.Il.c). 


\section{Literatura}

CoRnu F (1905) Enallogene Einschlüsse aus dem Nephelinbasalt von Jakuben in Böhmen. Tscherm Min Petr Mitt 24 (1-2): 143-145

Cornu F (1907) Mineralogische Notizen II. Mitt d naturwiss Ver a d Univ Wien V: 5, 53: 59

DVoŘÁk Z, Radoñ M, SVEJKovskÝ J, JaneČEK O, DVoŘÁk $P$, Fuchs P (2017) Minerály Českého středohoří. Muzeum města Ústí nad Labem, Ústí nad Labem

Fediuk F, Langrová A, MelKa K (2004) Vznik a rozpad hydroxyapofylitu $v$ komínové brekcii olivinického melililitu v Kytlicích u Nového Boru, severní Čechy. Miner Slov 36: 323-330

Fengl M, Mühlstein B, RYchlý R (1982) Pektolit z Těchlovic u Děčína. Čas Nár Muz, Odd Přírodověd 151, 2: 61-63

FIŠERA M, VICHR P, SEJKORA J (2002) Datolit a nepřeměněný fluorapofylit $z$ alpských žil $v$ amfibolitech $z$ Libodřic (jz. od Kolína). Bull mineral-petrolog Odd Nár Muz (Praha) 10: 210-215

FIŠERA V (1985) Perspektivní lokalita krystalovaných ukázek natrolitu v Těchlovicích j. od Děčína. Čas Mineral Geol 30, 3: 329

HIBSCH JE (1899) Erläuterungen zur geologischen Karte des böhmischen Mittelgebirges. Blatt II. (Rongstock -Bodenbach). Tscherm Min Petr Mitt 19, 1: 1-101

HIBSCH JE (1934) Die Minerale des Böhmischen Mittelgebirges. Verlag von Gustav Fischer, Jena

KADLEC T (2009) Pegmatity Vlastějovic. Minerál 17 (6): 467-479

LAUGIER J, BOCHU B (2011) LMGP-suite of programs for the interpretation of X-ray experiments. http://www.ccp14. ac.uk/tutorial//mgp, přístup duben 2011

Novák F, Pauliš P, Ševcư J (2004) Saponit z Těchlovic u Děčína. Zpr stud Region muz (Děčín) 25: 15-20
Novák JK, ChVátal M, Ulrych J, Wiesner T, Radoñ M (2001) Amygdale mineral paragenesis of trachybasalt from Kočičí hlava hill (Katzenkoppe) near Velké Březno, České středohoří Mts. - Sbor Prací Univ Palack, Geol 37: 1-26

PAULıŠ P, ŠıKola D (1999) Pyrit-zeolitová minerální asociace na uranovém ložisku Rožná. Minerál 7 (4): 310-314

Pelikan A (1902) Beträge zur Kenntnis der Zeolithe Böhmens. Sitz-Ber Akad Wiss, mathem-naturwiss KI 111, 1: $334-347$

Pouchou JL, PICHOIR F (1985) "PAP" ( $\varphi \rho Z)$ procedure for improved quantitative microanalysis. In: Microbeam Analysis (J. T. Armstrong, ed.). San Francisco Press, San Francisco: 104-106

RADOŇ M (2010) Historické a významné mineralogické lokality Českého středohoří a jejich současný stav. Sborník abstrakt a exkurzní průvodce 2. mezinárodního semináře Odborné skupiny vulkanologické ČGS, Teplice: 83-106

Reuss EA (1840) Geognostische Skizzen aus Böhmen. I. Band. Die Umgebungen von Teplitz und Bilin in Beziehung auf ihre geognostischen Verhältnisse. Ein Beitrag zur Physiographie des böhmischen Mittelgebirges. Prag Leitmeritz und Teplitz

Rouse RC, PEAcor DR, Dunn PJ (1978) Hydroxyapophyllite, a new mineral and a redefinition of the apophyllite group, Part II. Crystal structure. Am Mineral 63: 196202

SCHEIT A (1912) Eine regelmässige Verwachsung von Thomsonit und Natrolit. Tscherm Min Petr Mitt 31 (45): $495-500$

TVRDÝ J (2000) Fluorapofylit z Vlastějovic. Bull mineral -petrolog Odd Nár Muz (Praha) 8: 265-267

VILDNER R. (2010) Návrh na využití lomu Těchlovice po ukončení těžby - studie. MS, bakal. práce, VŠB-TU Ostrava 